\title{
Investigation of the Level of Serum Irisin in Patients With Gestational Diabetes Mellitus
}

\author{
Gestasyonel Diabetes Mellitusta Serum Irisin Düzeyinin AraștrıIması
}

\author{
Gulcan Kahraman', Mustafa Kahraman², Mesut Oterkus ${ }^{3}$ \\ ${ }^{I}$ Department of Gynecology and Obstetrics; ${ }^{2}$ Department of Anaesthesiology and Reanimation, Fethi Sekin City Hospital, Elazı̆g, Turkey; \\ ${ }^{3}$ Department of Anaesthesiology and Reanimation, Malatya Turgut Özal University, Malatya, Turkey
}

\begin{abstract}
Aim: In pregnancy, the most common metabolic disorder is Diabetes Mellitus (DM). Gestational diabetes mellitus (GDM) is glucose intolerance that first appears during pregnancy or is diagnosed. Especially in late pregnancy, the fetüs, rapidly growing glucose metabolism, directs glucose and amino acids to the fetus. The mother's energy needs are arranged in the provision (free fatty acids, ketones, and glycerol) from alternative sources. It is the irisin the main function is turning from white adipose tissue to brown adipose tissue, uncover energy as heat and induced by exercises, such as weight loss, reduction in insulin resistance, associated with obesity, glucose regulation and effects on lipid metabolism are known to have many physiological properties. This study, it is aimed to investigate the level of irisin, which is GDM involved in energy metabolism, a new hormone.
\end{abstract}

Material and Method: In Firat University Faculty of Medicine, Obstetrics and Gynecology Clinic, the 40 pregnant women diagnosed with GDM (Group 1) and 40 healthy pregnant women without any problems in pregnancy (Group 2) so that the total 80 patients were included in this study. These groups were divided into four subgroups, GDM in the second trimester, 20 patients (Group 1A), GDM in the third trimester, 20 patients (Group 1B), In the second trimester, 20 healthy patients (Group 2A), In the third trimester, 20 healthy patients (Group 2B).

Results: In this study compared with control groups, serum irisin levels were increased significantly, including the 2. trimester higher $(263.70 \pm 127.69 \mathrm{ng} / \mathrm{ml})$ in the GDM group. There was no correlation between serum irisin level and BMI.

Conclusion: In future studies, the necessity of questioned physical activity and exercise, the need for more extensive experimental and clinical studies, and if the pathophysiological mechanisms between the iris and GDM are illuminated, the clinical conclusion was reached irisin related options can be treated.

Key words: pregnancy; gestational diabetes mellitus; irisin; body mass index

\section{ÖZET}

Amaç: Gebelikte en sık karșılașılan metabolizma bozukluğu Diabetes Mellitus (DM)'dur. Gestasyonel Diabetes Mellitus (GDM) gebelikte ilk kez ortaya çıkan veya gebelik sırasında tanı konulan glukoz tolerans bozukluğudur. Özellikle gebeliğin son dönemlerinde glukoz metabolizması, hızla büyümekte olan fetüse glukoz ve aminoasitleri yönlendirerek annenin enerji ihtiyacının alternatif kaynaklardan (serbest yağ asitleri, ketonlar ve gliserol) sağlanması șeklinde düzenlenir. Temel fonksiyonu beyaz yağ dokusunu, kahverengi yağ dokusuna çevirerek enerjinin ısı olarak ortaya çıkmasını sağlamak olan ve egzersizle uyarılan irisin; kilo kaybı, insülin direncinde azalma, șișmanlık ile ilișkili olması, glukozun düzenlenmesi ve lipid metabolizmasında ki etkileri gibi birçok fizyolojik özelliğinin olduğu bilinmektedir. Bu çalıșmada; GDM'li hastalarda enerji metabolizmasında görev alan yeni bir hormon olan irisin düzeyinin incelenmesi amaçlanmıștır.

Materyal ve Metot: Çalıșmaya Fırat Üniversitesi Tıp Fakültesi Kadın Hastalıkları ve Doğum Kliniğinde GDM tanısıyla takip edilen 40 gebe (Grup 1) ve gebeliğinde herhangi bir problemi olmayan sağlıklı 40 gebe (Grup 2) olmak üzere toplam 80 hasta dahil edildi. Bu gruplar da kendi içerisinde GDM'li ikinci trimesterinde 20 hasta (Grup 1A), GDM'li üçüncü trimesterinde 20 hasta (Grup 1B) ve sağlıklı ikinci trimesterinde 20 hasta (Grup 2A), sağlıklı üçüncü trimesterinde 20 hasta (Grup 2B) olmak üzere 4 alt gruba ayrıldı.

Bulgular: Çalıșmamızda kontrol gruplarıyla karșılaștırıldığında 2. trimesterda daha yüksek olmakla üzere $(263,70 \pm 127,69 \mathrm{ng} /$ ml) GDM gruplarında serum irisin düzeyleri anlamlı olarak artmıș bulundu.

Sonuç: Ileride yapılacak çalıșmalarda fiziksel aktivite ve egzersizin sorgulanmasının gerekliliği, daha kapsamı deneysel ve klinik çaIıșmalara ihtiyaç olduğu ve GDM ile irisin arasındaki fizyopatolojik mekanizmalar aydınlatılabildiği takdirde klinik olarak irisin ile ilgili tedavi seçeneklerinin olabileceği kanaatine varılmıștır.

Anahtar kelimeler: gebelik; gestasyonel diabetes mellitus; irisin; vücut kitle indeksi

Iletișim/Contact: Mesut Öterkuş, Department of Anaesthesiology and Reanimation, Malatya Turgut Özal University, Malatya, Turkey • Tel:05438550954 • E-mail: mesutoterkus@hotmail.com • Gelis/Received:08.11.2020 • Kabul/Accepted: 10.03.2021

ORCID: Gülcan Kahraman, 0000-0003-2604-2455 • Mustafa Kahraman, 0000-0003-3554-3024 • Mesut Öterkus,, 0000-0003-1025-7662 


\section{Introduction}

Gestational Diabetes Mellitus (GDM) is a glucose tolerance disorder that first appeared during pregnancy or was diagnosed during pregnancy ${ }^{1}$. It is the most common metabolic disorder during pregnancy. In the baby, congenital malformation and intrauterine death can cause consequences. GDM is a metabolic disorder that can cause increased morbidity and mortality due to different disorders such as hypoglycemia, diabetic ketoacidosis, retinopathy, neuropathy, and nephropathy in the mother ${ }^{2}$.

As it is known, many metabolic and hormonal changes occur during pregnancy. The main purpose of these changes is to provide the fetus with sufficient energy. It is known as the first-trimester anabolic period and is when gluconeogenesis is increased. An increase characterizes maternal protein, glycogen, and fat stores. In this period, because insulin sensitivity increases, there is a tendency to hypoglycemia and ketosis. The second half of pregnancy is the catabolic period. Maternal metabolism is affected by placental hormones. With the effect of these hormones, carbohydrate use decreases, lipolysis increases, maternal adipose mass decreases, and insulin resistance dominate the table. While the mother uses glycerol, free fatty acids, and ketones as the main energy source, Glucose and amino acids are stored for the need of the fetus ${ }^{3,4}$. As the week of pregnancy progresses, insulin resistance increases. Human placental lactogen (HPL), progesterone, cortisol, growth hormone, and prolactin are the most important anti-insulin hormones that cause insulin resistance ${ }^{2,5}$. In response to developing insulin resistance, pancreatic beta cells develop hyperplasia, and insulin secretion increases ${ }^{6-8}$. However, it is unable to respond to secretion.

One of the hormones involved in energy metabolism is the 112 amino acid peptide irisin, discovered by Bostrom et al. in 20129. The exercise-induced iris is synthesized from muscle tissue, and it converts white adipose tissue to brown adipose tissue, revealing energy in the form of heat ${ }^{10}$. Irisin causes a decrease in insulin resistance and affects glucose and lipid metabolism $^{11,12}$. It has been demonstrated a protective role in nutritional obesity and diabetes in experimental animals?.

This study aims to examine the level of irisin, a new hormone involved in energy metabolism in patients with GDM.

\section{Materials and Methods}

After obtaining the necessary ethics committee permission from the Firat University Faculty of Medicine Clinical Research Ethics Committee with the datedecision number 02.08.2013/02-02, Between the ages of 18-40 and At 24-28 weeks of pregnancy, who were followed up in the Firat University Faculty of Medicine Hospital between August 2013 and March 2014 total of 80 volunteer participants were included in our study, including 40 cases with diagnosed with GDM and 40 healthy pregnant women. Informed consent was obtained from all patients. Both groups were divided into two subgroups: pregnant women in their second and third trimesters.

- Group 1 ( $\mathrm{n}=40)$ : Group with Gestational Diabetes Mellitus

- Group 1A ( $n=20)$ : Pregnant women in the second trimester

- Group 1B ( $n=20)$ : Pregnant women in the third trimester

- Group 2 ( $\mathrm{n}=40)$ : Healthy pregnant (control) group

- Grup 2A ( $n=20)$ : Pregnant women in the second trimester

- Grup 2B ( $\mathrm{n}=20)$ : pregnant women in the third trimester

Demographic data (height, age, weight), body mass index, gravida, parity, number of abortions, systolic arterial blood pressures measurements (SAP), diastolic arterial blood pressures measurements (DAP), gestational week $(\mathrm{Gw})$, and obstetric ultrasonographic information were recorded. Whole blood, biochemistry, and urine analyzes were performed and recorded.

\section{Statistical analysis}

SPSS 12.0 (The Statistical Package for the Social Sciences, Chicago, USA) program was used for statistical analysis. The data obtained were recorded as mean \pm SD. Variation analysis (ANOVA) was used to analyze parametric tests, and a post-Tukey HSD test was used when a significant difference was found in the comparison between the groups. Paired t test was used to compare repetitive measurements within the group. Values with $\mathrm{P}<0.05$ were considered statistically significant. 


\section{Results}

Groups are similar in demographic data of patients ( $>0.05)$ (Table 1). When BMI, systolic, and diastolic arterial pressure values were analyzed; There was no statistically significant difference between groups $(p>005)$. Similarly, when gestational weeks were examined, no difference was found between the groups $(p>0.05)$. In terms of gravida and parity; There was a statistically significant increase in Group 1A compared to Group 2A and Group 1B compared to Group 2B. $(\mathrm{P}<0.05)$. There was no difference in abortion between the groups $(\mathrm{p}>0.05)$.

When serum irisin levels were examined; It was found higher in the 2. trimester group with GDM (Group 1A) than the 2. Trimester healthy group (Group 2A). Likewise, in the 3. The trimester grup with GDM (Group 1B) was significantly higher than the 3. trimester healthy group (Group $2 B)(p<0.05)$. In the comparison within the group, the iris level was statistically higher in both groups in the $2 \mathrm{nd}$ trimester $(p<0.05)$. When we look at the correlation between body mass index and iris; Weak negativity in the GDM group ( $\mathrm{r}=-0.075,-0.19)$, whereas in the control group, weak positivity $(r=0.33,0.03)$ was found, but it was not statistically significant. Demographic, Clinical, and biochemical data are given in Table 1.

\section{Discussion}

The main purpose of metabolic changes in the mother during pregnancy is to provide the fetus with enough energy. It is known as the first-trimester anabolic period and is characterized by increased gluconeogenesis, maternal protein, glycogen, and fat stores. The energy stored in the first trimester is used to meet the needs of the growing fetus in later periods. Fasting blood glucose level is lower due to the peripheral use of glucose increases. The second half of pregnancy is the catabolic period and increased HPL secreted by syncytiotrophoblasts. HPL increases lipolysis in adipose tissue, and glucose and amino acids are stored for the fetus's need. HPL, progesterone, cortisol, and prolactin are hormones responsible for insulin resistance and act by disrupting the glucose uptake of insulin-sensitive cells. However, it is known that there is no decrease in insulin receptors during pregnancy ${ }^{10}$.

Pregnancies complicated by diabetes are risky pregnancies that require close monitoring both maternally and fetally. When adequate glycemic control cannot be achieved, it can cause congenital malformations and in-utero death in the baby. The mother is a metabolic disorder that can cause morbidity and mortality due to increased hypoglycemia, diabetic ketoacidosis, retinopathy, and nephropathy.

Table 1. Demographic, clinical and biochemical data

\begin{tabular}{|c|c|c|c|c|}
\hline & \multicolumn{2}{|c|}{ Grup $1(n=40)$} & \multicolumn{2}{|c|}{ Grup $2(n=40)$} \\
\hline & $\begin{array}{c}\text { Grup 1A } \\
(n=20)\end{array}$ & $\begin{array}{l}\text { Grup 1B } \\
(n=20)\end{array}$ & $\begin{array}{l}\text { Grup 2A } \\
(n=20)\end{array}$ & $\begin{array}{r}\text { Grup 2B } \\
(n=20)\end{array}$ \\
\hline Age (year) & $29.75 \pm 3.87$ & $35.45 \pm 5.94$ & $26.40 \pm 5.78$ & $29.55 \pm 6.41$ \\
\hline Weight (kg) & $72.75 \pm 12.31$ & $74.55 \pm 11.98$ & $68.00 \pm 7.00$ & $73.38 \pm 11.4$ \\
\hline Length (cm) & $161.00 \pm 6.05$ & $162.05 \pm 6.34$ & $162.90 \pm 6.39$ & $161.30 \pm 5.42$ \\
\hline Irisin (ng/ml) & $263.70 \pm 127.69^{a}$ & $192.29 \pm 84.84^{b}$ & $201.06 \pm 87.8$ & $129.33 \pm 53.8$ \\
\hline $\mathrm{BMI}$ & $27.73 \pm 4.13$ & $28.41 \pm 4.56$ & $25.58 \pm 2.02$ & $28.23 \pm 4.56$ \\
\hline Gw & $25.50 \pm 1.23$ & $35.50 \pm 3.31$ & $23.90 \pm 2.33$ & $33.20 \pm 3.44$ \\
\hline $\mathrm{SAP}(\mathrm{mmHg})$ & $108.50 \pm 16.63$ & $113.75 \pm 16.04$ & $113.75 \pm 12.7$ & $109.75 \pm 8.80$ \\
\hline $\mathrm{DAP}(\mathrm{mmHg})$ & $71.00 \pm 11.19$ & $70.50 \pm 9.98$ & $69.23 \pm 9.77$ & $70.75 \pm 8.31$ \\
\hline Gravida* & $2(1-6)^{a}$ & $4(1-9)^{b}$ & $1(1-4)$ & $2(1-5)$ \\
\hline Parite* $^{*}$ & $2(1-6)^{a}$ & $2(0-9)^{b}$ & $0(0-2)$ & $1(0-3)$ \\
\hline Abortus * & $0(0-3)$ & $0(0-2)$ & $0(0-2)$ & $0(0-3)$ \\
\hline
\end{tabular}

${ }^{*}$ Median (minimum-maximum), values are given as mean \pm standard deviation. BMI, Body mass index; GW, Pregnancy week; SAP, Systolic blood pressure; DAP, Diastolic blood pressure; a Compared to Group $2 A .{ }^{b}$ Compared to Group $2 B(p<0.05)$. 
It plays a role in peptides called adipokine and myokin in energy metabolism. One of the newly discovered myokines is irisine and plays a role in energy and thermogenesis ${ }^{9}$. By releasing the irisin from the muscle, it turns the white adipose tissue into brown adipose tissue and plays an important role in energy consumption and thermogenesis ${ }^{13,14}$. In addition, it was observed that the iris caused weight loss and an increase in oxygen consumption'. It also has positive effects on glucose metabolism ${ }^{9}$. In this study, we aim to investigate the level of irisin in patients with gestational diabetes mellitus.

In this study, serum irisin level in comparison between groups; was found higher in the 2 nd-trimester group with GDM than the healthy 2 nd-trimester group. In addition, the 3rd-trimester group with GDM was significantly higher than the 2 nd-trimester healthy group. In the comparison within the group; In both groups, irisin levels in the 2 nd trimester were found to be statistically higher.

Similar to our study, Ebert et al. found that average irisin levels were higher in patients with GDM in their study on 148 patients, including 74 GDM and 74 healthy pregnant women ${ }^{14}$. Likewise, Gümüş et al. found that serum irisin levels were higher in the GDM group than healthy group ${ }^{13}$. However, Kuzmicki et al. compared 130 GDM and 140 control groups in their study and found that serum irisin concentration was significantly increased in pregnant women but markedly lower in women with $\mathrm{GDM}^{15}$. Similar to this study, Guardiola-Diaz et al. and Hojlund et al. found a statistically significant low in patients with type $2 \mathrm{DM}^{16,17}$. Serum irisin levels were found low in type 2 diabetes in a study by Choi et al. ${ }^{18}$. It has been concluded that the iris can play an important role in glucose intolerance and type 2 diabetes. Aydin et al. likewise found that serum irisin levels decreased significantly in patients with GDM and thought that this decrease was associated with insulin resistance ${ }^{19}$.

These studies were in contrast with our findings. This contrast in our study may be due to some controversial limitations and different treatment protocols of patients with GDM. Also, due to the exercise levels of the patients being unknown, different results may be obtained because exercise is an essential factor in the secretion of the iris. Gümüş et al. evaluated irisin levels with the frequency of exercising in his study and found that irisin levels in the exercising group were statistically significantly higher than the non-exercising group ${ }^{13}$. Similarly, in animal studies, it was found that irisin levels increased with exercise stimulation ${ }^{20}$. As a result of these studies, it can be said that physical activity and exercise reveal the necessity of questioning thoroughly.

In our study, when the correlation between irisin level and body mass index and irisin was examined, a low negative correlation was observed in the GDM group, and a low positive correlation was observed in the control group. However, this correlation was not statistically significant. Stengel et al. As a result of the study involving individuals with anorexia nervosa and obese individuals; A positive correlation has been reported between BMI and irisin levels ${ }^{21}$. As a result of their study, they also found that iris levels had a positive correlation with BMI. they concluded that the main factor contributing to serum irisin levels in body fat mass $^{22}$. Gümüş et al. Similarly, their studies have shown a positive relationship between irisin level and BMI values before pregnancy ${ }^{13}$.

\section{Conclusion}

Our study; We found that serum irisin levels were significantly higher in GDM pregnant women compared to control groups, and there was no correlation between BMI and irisin. However, more comprehensive experimental and clinical studies are needed. We believe there may be treatment options related to irisin clinically if physiopathological mechanisms between GDM and irisin can be elucidated.

\section{References}

1. American Diabetes Association. Gestational Diabetes Mellitus. Diabetes Care 2003;26:103-105.

2. Kuhl C. Glucose metabolism during and after pregnancy in normal and gestational diabetic women. Acta Endocrinol 1995;79:709.

3. Barbour LA, McCundy CE, Hernandez TL. Cellular mechanisms for insulin resistance in normal pregnancy and gestational diabetes. Diabetes Care 2007;30:112-119.

4. Butte NF. Carbohydrate and lipid metabolism in pregnancy: normal compared with gestational diabetes mellitus. Am J Clin Nutr 2000;71:1256-1261.

5. Friedman JE, Ishizuka T, Shao J, Huston L, Highman T, Catalano P. Impaired glucose transport and insulin receptor tyrosine phosphorylation in skeletal muscle from obese women with gestational diabetes. Diabetes 1999;48:1807-1814. 
6. Yamashita H, Shao J, Friedman JE. Physiologic and molecular alterations in carbohydrate metabolism during pregnancy and gestational diabetes mellitus. Clin Obstet Gynecol 2000;43:8798.

7. Catalano PM, Kirwan JP, Haugel-de Mouzon S, King J. Gestational diabetes and insulin resistance: role in shortand long-term implications for mother and fetus. J Nutr 2003; 133:1674-1683.

8. Felice P, Donato D. Maternal endocrine and metabolic adaptation to pregnancy. Uptodate May 2012.

9. Bostrom P, Wu J, Jedrychowski MP, Korde A, Ye L, Lo JC, et al. A PGC1-alpha-dependent myokine that drives brownfat-like development of white fat and thermogenesis. Nature 2012;481:463-468.

10. Timmons JA, Baar K, Davidsen PK, Atherton PJ. Is irisin a human exercise gene? Nature 2012;488:9-10.

11. Aydin S, Kuloglu T, Aydin S. Copeptin, adropin and irisin concentrations inbreast milk and plasma of healthy women and those with gestational diabetes mellitus. Peptides 2013;47:6670.

12. Liu JJ, Liu S, Wong MD, Tan CS, Tavintharan S, Sum CF, Lim SC. Relationship between circulating irisin, renal function and body composition in type 2 diabetes. J Diabetes Complications 2014;28:208-213.

13. Gümüş A. T. Gestasyonel diyabetli hastalarda irisinin insülin direnci ile olan ilişkisi. Yan Dal Uzmanlık Tezi, İzmir: Dokuz Eylül Üniversitesi Tip Fakültesi, Endokrin ve Metabolizma Hastalıkları Bilim Dalı, 2013.

14. Ebert T, Stepan H, Schrey S, Kralisch S, Hindricks J, Hopf L, et al. Serum levels of irisin in gestational diabetes mellitus during pregnancy and after delivery. Cytokine 2014;65:153-158.
15. Kuzmicki M, Telejko B, Lipinska D, Pliszka J, Szamatowicz M, et al. Serum irisin concentration in women with gestational diabetes. Gynecol Endocrinol 2014;30:636-639.

16. Guardiola-Diaz HM, Rehnmark S, Usuda N, Albrektsen T, Feltkamp D, Gustafsson JA, Alexson SE. Rat peroxisome proliferator-activated receptors and brown adipose tissuefunetion during cold acclimatization. Biol Chem 1999;274:23368-23377.

17. Hojlund K. Bostrom P. İrisin in obesity and type 2 diabetes. J Diabetes Complications 2013;27:303-304.

18. Choi YK, Kim MK, Bae KH, Seo HA, JeongJY, Lee WK, et al. Serum irisin levels in new-onset type 2 diabetes. Diabetes Res Clin Pract 2013;100:96-101.

19. Aydin S, Kuloglu T, Aydin S. Copeptin, adropin and irisin concentrations inbreast milk and plasma of healthy women and those with gestational diabetes mellitus. Peptides 2013;47:6670.

20. Baar K, Wende AR, Jones TE, Marison M, Nolte LA, Chen $\mathrm{M}$, et al. Adaptations of skeletal musde to exercise: rapid increase in the transcrlptional coactivator PGC-1. FASEB J 2002;16:1879-1886.

21. Stengel A, Hofmann T, Goebel-Stengel M, Elbelt U, Kobelt P, Klapp BF. Circulating levels of irisin in patients with anorexia nervosa and different stages ofobesity - Correlation with body mass index. Peptides 2013;39:125-130.

22. Pardo M, Crujeiras AB, Amil M, Aguera Z, Jiménez-Murcia $S$, Baños R, et al. Association of irisin with fat mass, resting energy expenditure, and daily activity in conditions of extreme body mass index. Int J Endocrinol 2014;2014:857270. 